\title{
Abstention from smoking extends life and compresses morbidity: a population based study of health expectancy among smokers and never smokers in Denmark
}

\author{
Henrik Brønnum-Hansen, Knud Juel
}

\begin{abstract}
Objective-To estimate health expectancythat is, the average lifetime in good health-among never smokers, exsmokers, and smokers in Denmark.

Design-A method suggested by Peto and colleagues in 1992 for estimating smoking attributable mortality rates was used to construct a life table for never smokers. This life table and relative risks for death for ex-smokers and smokers versus never smokers were used to estimate life tables for ex-smokers and smokers. Life tables and prevalence rates of health status were combined and health expectancy was calculated by Sullivan's method.

Setting-The Danish adult population.

Main outcome measures-The expected lifetime in self rated good health or without longstanding illness for never smokers and smokers.

Results-The expected lifetime of a 20 year old man who will never begin to smoke is 56.7 years, 48.7 (95\% confidence interval (CI), 46.8 to 50.7) years of which are expected to be in self rated good health. The corresponding figures for a man who smokes heavily are 49.5 years, 36.5 (95\% CI 35.0 to 38.1 ) years of which are in self rated good health. A 20 year old woman who will never begin to smoke can expect to live a further 60.9 years, with $46.4(95 \%$ CI 44.9 to 47.8$)$ years in self rated good health; if she is a lifelong heavy smoker, her expected lifetime is reduced to 53.8 years, 33.8 (95\% CI 31.7 to 35.9$)$ years of which are in self rated good health. Health expectancy based on long standing illness is reduced for smokers when compared with never smokers.

Conclusions-Smoking reduces the expected lifetime in good health and increases the expected lifetime in poor health.

(Tobacco Control 2001;10:273-278)
\end{abstract}

National Institute of Public Health, Copenhagen, Denmark

Correspondence to: Henrik Brønnum-Hansen, National Institute of Public Health, 25 Svanemøllevej, DK 2100 Copenhagen Ø, Denmark

hbh@niph.dk

Received 9 February 2001 and in revised form

10 May 2001. Accepted

1 June 2001 deaths among men and $18 \%$ among women. ${ }^{1}$ The impact of tobacco smoking on public health can also be evaluated by comparing health expectancy - that is, the average lifetime in good health-between never smokers and smokers; furthermore, the hypothesis that abstention from smoking compresses morbidity can be examined. ${ }^{2}$

To our knowledge, the effect of smoking on health expectancy has not previously been estimated from national data. The purpose of the present study was to compare expected lifetime in self rated good health or without longstanding illness between Danish never smokers and smokers.

\section{Methods}

A commonly used method for health expectancy calculation is Sullivan's method. ${ }^{3}$ The method requires life tables and data on the prevalence of health status. Thus, to estimate health expectancy among never smokers, ex-smokers, moderate, and heavy smokers we need life tables for each smoking category. The first step in the calculation of health expectancy is therefore to construct these life tables. The Danish National Cohort Study (DANCOS), established by linking data from the Danish Health Interview Survey for 1987, 1991, and 1994 with the Cause of Death Register and other national registers does not include enough persons followed up for a sufficient length of time to estimate life tables classified by sex and smoking category. But DANCOS makes it possible to estimate relative risks for death for ex-, moderate, and heavy smokers versus never smokers. The relative risk estimates and a life table for never smokers constructed on the basis of a method proposed by Peto and colleagues ${ }^{4}$ can be used to estimate life tables classified by sex and smoking category. The final step in estimating health expectancy is to combine life table data and prevalence of health status by smoking category. The details of the calculations are described below.

ESTIMATING LIFE TABLES FOR NEVER SMOKERS, EX-SMOKERS, AND SMOKERS

The size of the second prospective Cancer Prevention Study (CPS-II) of the American Cancer Society on smoking and mortality allowed estimation of lung cancer death rates among people who had never smoked. By use of a method suggested by Peto and colleagues, ${ }^{4}$ we calculated the proportion of smoking 
attributable deaths from lung cancer in 1991 to 1995 from the rates of death from lung cancer in Denmark and the rates for never smokers and smokers estimated from the CPS-II. We then estimated a sex and age specific "synthetic smoking prevalence" rate for Denmark, which is the prevalence that would be necessary to result in the observed rate of death from lung cancer in the population. Indirectly it includes the influence of the proportion of smokers, the amount smoked, the duration of smoking, the age at starting to smoke, and the prevalence of inhaling. On the basis of the "synthetic smoking prevalence" and relative risks taken from the CPS-II, we calculated the aetiological fractions for other smoking related causes of death: upper aerodigestive cancers, other cancers, chronic obstructive lung disease, other diseases of the respiratory system, vascular diseases, and other natural causes. However, in order to control for confounding and ensure that the hazards of tobacco were not exaggerated the aetiological fraction $\mathrm{P}(\mathrm{RR}-1)$ / $(1+\mathrm{P}(\mathrm{RR}-1))$ was replaced by $\mathrm{P}(\mathrm{RR}-1) /$ $(2+\mathrm{P}(\mathrm{RR}-1))$, according to the method of Peto and colleagues. ${ }^{4}$ Thus, deaths caused by smoking and deaths not caused by smoking were calculated. In particular, life tables for never smoking men and women could be estimated. DANCOS made it possible to estimate relative risks for death for ex-, moderate, and heavy smokers versus never smokers. The estimates found were 1.1 for ex-smokers, 1.3 for moderate smokers, and 2.2 for heavy smokers. Age specific death rates for never smokers were multiplied by relative risk estimates giving age specific death rates for each smoking category. Nevertheless, because of the long delay before smoker's risk for death is increased, the relative risks (RRs) for people under 45 were reduced to $(R R+1) / 2$. Finally, life tables by smoking category were constructed. The method is described in greater detail in appendix 1 .

DANISH HEALTH INTERVIEW SURVEY DATA Data on the health of the Danish population were collected in 1991 and 1994 by interviewing representative, random samples of Danes extracted from the Danish Civil Registration System. Each of the two independent cross sectional surveys comprised approximately 6000 Danes aged 16 years or over. In order to eliminate seasonal variation, interviews were conducted in three rounds, in February, May, and September, each comprising about 2000 interviews, by professional interviewers from the Danish National Institute of Social Research who were carefully instructed before visiting the participants. In the 1991 survey, questions on smoking were asked only in the third round, and only data from that round were included in the present study. Interviews were obtained with about $80 \%$ of the subjects. The rate of refusal to participate was almost the same for men and women, but it increased with age and was highest among single persons and among persons in the metropolitan area. ${ }^{56}$ As the questions in the two health surveys that were relevant for this study were identical, the data were combined and were considered to represent the health status of Danish adult at the beginning of the 1990s. The present study included respondents aged 20 years or more, comprising 2766 men and 3045 women.

Self rated health was based on answers to the question: "How would you rate your present state of health in general?" The five original response categories (very good, good, fair, poor, and very poor) were dichotomised into "good" and "fair or poor". Longstanding illness was determined on the basis of answers to the question: "Do you suffer from any longstanding illness, longstanding sequelae from injury, handicap or other longstanding complaint?" Whenever longstanding illness was reported, its nature was clarified by means of an open question. The answers to this question were subsequently coded according to the World Health Organization's International Classification of Diseases and grouped into one of 14 disease groups. ${ }^{6}$

The interviewees were categorised as never smokers, ex-smokers, moderate smokers (1-14 g of tobacco per day), and heavy smokers ( $\geqslant 15 \mathrm{~g}$ of tobacco per day) according to answers to the question "Do you smoke?", with the answer categories "Yes, daily", "Yes, but some days I don't smoke", and "No", and questions on the amount of tobacco smoked. The question: "Have you ever been a smoker?" was asked to identify ex-smokers.

\section{ESTIMATING HEALTH EXPECTANCY}

Health expectancy was calculated by Sullivan's method, ${ }^{3}$ by combining life tables and prevalence rates of health status. On the basis of the life table figures, we calculated the expected numbers of years lived in age groups of five years. The proportion of healthy people in each age group was taken from the health survey data, and the number of years in good health was estimated. Health expectancy from a given age was then calculated by adding these years and relating the sum to the number of survivors at that age. By relating health expectancy to life expectancy, a measure of the proportion of lifetime in good health was established. Confidence intervals were estimated by the formulae suggested by the International Network on Health Expectancy (REVES). ${ }^{7}$ The method is summarised in appendix 2 .

\section{Results}

Life expectancy at age 20 was seven years shorter for heavy smokers than for never smokers, whereas, at age 65 , the difference was a little more than five years. Life expectancy for a never smoking 20 year old man was 56.7 years, 48.7 of which were expected to be spent in self rated good health. The expected lifetime in self rated fair or poor health was 8.0 years $(56.7$ years -48.7 years). The 48.7 years in good health account for $85.9 \%$ of the remaining expected lifetime of 56.7 years (table 1). A 20 year old male lifelong heavy smoker could expect to live only 36.5 years of his remaining lifetime of 49.5 years in self rated good health 
Table 1 Expected lifetime and proportion of expected lifetime in self rated good health at ages 20 and 65 among never smokers, ex-smokers, moderate smokers, and heavy smokers

\begin{tabular}{|c|c|c|c|c|c|c|c|}
\hline \multirow[b]{2}{*}{$\begin{array}{l}\text { Age } \\
\text { (years) }\end{array}$} & \multirow[b]{2}{*}{ Smoking category } & \multicolumn{3}{|l|}{ Men } & \multicolumn{3}{|l|}{ Women } \\
\hline & & $\begin{array}{l}\text { Life } \\
\text { expectancy } \\
\text { (years) }\end{array}$ & $\begin{array}{l}\text { Expected lifetime in self } \\
\text { rated good health } \\
\text { (years }(95 \% \text { CI) })\end{array}$ & $\begin{array}{l}\text { Proportion of expected } \\
\text { lifetime in self rated good } \\
\text { health }(\%(95 \% \text { CI }))\end{array}$ & $\begin{array}{l}\text { Life } \\
\text { expectancy } \\
\text { (years) }\end{array}$ & $\begin{array}{l}\text { Expected lifetime in self } \\
\text { rated good health } \\
\text { (years }(95 \% \mathrm{CI}) \text { ) }\end{array}$ & $\begin{array}{l}\text { Proportion of expected } \\
\text { lifetime in self rated good } \\
\text { health }(\%(95 \% \mathrm{CI}))\end{array}$ \\
\hline \multirow[t]{5}{*}{20} & Never smoker & 56.7 & 48.7 (46.8 to 50.7$)$ & $85.9(82.5$ to 89.3$)$ & 60.9 & 46.4 (44.9 to 47.8$)$ & 76.1 (73.7 to 78.6$)$ \\
\hline & Ex-smoker & 55.9 & 45.0 (43.5 to 46.6$)$ & $80.6(77.8$ to 83.4$)$ & 60.0 & 44.7 (42.8 to 46.7$)$ & 74.5 (71.3 to 77.8$)$ \\
\hline & Moderate smoker & 54.3 & $44.8(43.0$ to 46.5$)$ & $82.4(79.2$ to 85.6$)$ & 58.5 & $43.2(41.2$ to 45.1$)$ & $73.7(70.4$ to 77.1$)$ \\
\hline & Heavy smoker & 49.5 & $36.5(35.0$ to 38.1$)$ & $73.8(70.6$ to 76.9$)$ & 53.8 & $33.8(31.7$ to 35.9$)$ & $62.9(59.0$ to 66.7$)$ \\
\hline & All & 53.7 & $43.1(42.3$ to 43.9$)$ & $80.2(78.8$ to 81.7$)$ & 58.7 & $43.0(42.1$ to 43.9$)$ & $73.4(71.8$ to 74.9$)$ \\
\hline \multirow[t]{5}{*}{65} & Never smoker & 16.4 & 11.7 ( 9.8 to 13.6$)$ & $71.2(59.8$ to 82.6$)$ & 19.1 & 10.0 ( 8.8 to 11.2$)$ & $52.3(46.3$ to 58.4$)$ \\
\hline & Ex-smoker & 15.7 & $9.3(8.3$ to 10.3$)$ & $59.1(52.7$ to 65.6$)$ & 18.4 & $10.4(9.1$ to 11.8$)$ & $56.4(49.1$ to 63.8$)$ \\
\hline & Moderate smoker & 14.6 & $9.3(8.0$ to 10.7$)$ & 64.1 (54.9 to 73.3$)$ & 17.3 & $8.9(7.4$ to 10.4$)$ & $51.7(43.0$ to 60.4$)$ \\
\hline & Heavy smoker & 11.2 & $6.9(5.9$ to 7.9$)$ & $61.6(52.3$ to 71.0$)$ & 13.8 & $4.4(2.8$ to 6.0$)$ & $32.0(20.2$ to 43.8$)$ \\
\hline & All & 14.2 & $8.8(8.2$ to 9.4$)$ & 62.0 (57.7 to 66.3$)$ & 17.7 & 9.5 ( 8.8 to 10.2$)$ & $53.4(49.5$ to 57.3$)$ \\
\hline
\end{tabular}

and 13.0 years in fair or poor health. The corresponding results for ex-smokers and moderate smokers lay between those of never smokers and heavy smokers (table 1). Analogous differences were found for 20 year old never smoking, ex-smoking, and smoking women (table 1), and a similar pattern was seen at older ages. The results for 65 year olds are shown in table 1 .

Table 2 shows that the expected lifetime without longstanding illness for a 20 year old male lifelong heavy smoker was 29.0 years, which was 7.6 years shorter than that of a never smoking man. The expected lifetime with longstanding illness of 20 year old men was about 20 years for both never smokers and heavy smokers. For women, the situation was even worse, the difference in expected lifetime without longstanding illness being 11.4 years.

A 20 year old female lifelong heavy smoker could expect 4.3 years more with longstanding illness than a never smoker. No significant difference in expected lifetime without longstanding illness was found between never smokers, ex-smokers, and moderate smokers.

The columns in tables 1 and 2 showing the proportion of expected lifetime in self rated good health and without longstanding illness, respectively, show the compression of morbidity achieved by abstention from smoking. This is further elucidated in absolute terms in table 3 , showing the difference in the numbers of expected healthy and unhealthy life-years between never smokers and ex-, moderate, and heavy smokers. For instance, a 20 year old male lifelong heavy smoker could expect to lose 12.2 years in self rated good health and add 5.0 years in fair or poor health.

Musculoskeletal diseases accounted for the highest proportion of longstanding illness, and

Table 2 Expected lifetime and proportion of expected lifetime without longstanding illness at ages 20 and 65 among never smokers, ex-smokers, moderate smokers, and heavy smokers

\begin{tabular}{|c|c|c|c|c|c|c|c|}
\hline \multirow[b]{2}{*}{$\begin{array}{l}\text { Age } \\
\text { (years) }\end{array}$} & \multirow[b]{2}{*}{ Smoking category } & \multicolumn{3}{|l|}{ Men } & \multicolumn{3}{|l|}{ Women } \\
\hline & & $\begin{array}{l}\text { Life } \\
\text { expectancy } \\
\text { (years) }\end{array}$ & $\begin{array}{l}\text { Expected lifetime } \\
\text { without longstanding } \\
\text { illness (years }(95 \% \mathrm{CI}) \text { ) }\end{array}$ & $\begin{array}{l}\text { Proportion of expected } \\
\text { lifetime without } \\
\text { longstanding illness } \\
(\%(95 \% \mathrm{CI}))\end{array}$ & $\begin{array}{l}\text { Life } \\
\text { expectancy } \\
\text { (years) }\end{array}$ & $\begin{array}{l}\text { Expected lifetime } \\
\text { without longstanding } \\
\text { illness (years (95\% CI)) }\end{array}$ & $\begin{array}{l}\text { Proportion of expected } \\
\text { lifetime without } \\
\text { longstanding illness } \\
(\%(95 \% \text { CI }))\end{array}$ \\
\hline \multirow[t]{5}{*}{20} & Never smoker & 56.7 & $36.6(34.2$ to 39.0$)$ & 64.5 (60.3 to 68.7$)$ & 60.9 & 36.1 (34.4 to 37.8$)$ & $59.3(56.5$ to 62.1$)$ \\
\hline & Ex-smoker & 55.9 & $35.0(32.9$ to 37.0$)$ & 62.6 (58.9 to 66.2$)$ & 60.0 & 35.6 (33.3 to 37.8$)$ & $59.3(55.6$ to 63.0$)$ \\
\hline & Moderate smoker & 54.3 & 36.0 (33.8 to 38.2$)$ & $66.3(62.3$ to 70.4$)$ & 58.5 & 37.1 (35.0 to 39.2$)$ & $63.4(59.7$ to 67.1$)$ \\
\hline & Heavy smoker & 49.5 & $29.0(27.2$ to 30.7$)$ & 58.5 (55.0 to 62.0$)$ & 53.8 & 24.6 (22.7 to 26.6$)$ & 45.8 (42.1 to 49.5$)$ \\
\hline & All & 53.7 & 33.5 (32.6 to 34.5$)$ & $62.5(60.7$ to 64.3$)$ & 58.7 & 33.9 (32.9 to 34.9$)$ & 57.8 (56.1 to 59.5$)$ \\
\hline \multirow[t]{5}{*}{65} & Never smoker & 16.4 & $8.2(6.1$ to 10.3$)$ & 50.1 (37.4 to 62.7$)$ & 19.1 & $7.0(5.9$ to 8.1$)$ & $36.6(30.7$ to 42.5$)$ \\
\hline & Ex-smoker & 15.7 & $6.9(5.9$ to 7.9$)$ & $43.8(37.2$ to 50.3$)$ & 18.4 & $7.7(6.3$ to 9.0$)$ & 41.6 (34.2 to 49.0$)$ \\
\hline & Moderate smoker & 14.6 & $8.6(7.2$ to 10.0$)$ & $59.2(49.7$ to 68.7$)$ & 17.3 & $8.1(6.6$ to 9.6$)$ & $46.9(38.2$ to 55.7$)$ \\
\hline & Heavy smoker & 11.2 & $4.6(3.6$ to 5.6$)$ & 40.9 (31.8 to 50.0$)$ & 13.8 & $1.7(0.5$ to 2.9$)$ & $12.4(3.6$ to 21.3$)$ \\
\hline & All & 14.2 & $6.7(6.1$ to 7.3$)$ & 47.1 (42.7 to 51.5$)$ & 17.7 & $6.9(6.2$ to 7.6$)$ & 38.8 (35.1 to 42.6$)$ \\
\hline
\end{tabular}

Table 3 Reduction in life expectancy, expected healthy life-years lost and expected unhealthy life-years added for 20 and 65 year old ex-, moderate, and heavy smokers compared with never smokers

\begin{tabular}{|c|c|c|c|c|c|c|c|}
\hline \multirow[b]{2}{*}{$\begin{array}{l}\text { Age } \\
\text { (years) }\end{array}$} & \multirow[b]{2}{*}{ Smoking category } & \multirow[b]{2}{*}{ Sex } & \multirow[b]{2}{*}{$\begin{array}{l}\text { Reduced life } \\
\text { expectancy (years) }\end{array}$} & \multicolumn{2}{|c|}{ Expected healthy life-years lost } & \multicolumn{2}{|c|}{ Expected unhealthy life-years added } \\
\hline & & & & $\begin{array}{l}\text { In self rated good } \\
\text { health (years) }\end{array}$ & $\begin{array}{l}\text { Without longstanding } \\
\text { illness (years) }\end{array}$ & $\begin{array}{l}\text { In self rated fair or } \\
\text { poor health (years) }\end{array}$ & $\begin{array}{l}\text { With longstanding } \\
\text { illness (years) }\end{array}$ \\
\hline \multirow[t]{6}{*}{20} & \multirow[t]{2}{*}{ Ex-smoker } & Men & 0.9 & 3.7 & 1.6 & 2.8 & 0.8 \\
\hline & & Women & 0.9 & 1.6 & 0.5 & 0.8 & -0.3 \\
\hline & \multirow[t]{2}{*}{ Moderate smoker } & Men & 2.4 & 4.0 & 0.6 & 1.6 & -1.9 \\
\hline & & Women & 2.4 & 3.2 & -1.0 & 0.8 & -3.4 \\
\hline & \multirow[t]{2}{*}{ Heavy smoker } & Men & 7.2 & 12.2 & 7.6 & 5.0 & 0.4 \\
\hline & & Women & 7.1 & 12.6 & 11.4 & 5.5 & 4.3 \\
\hline \multirow[t]{6}{*}{65} & \multirow[t]{2}{*}{ Ex-smoker } & Men & 0.7 & 2.4 & 1.3 & 1.7 & 0.7 \\
\hline & & Women & 0.7 & -0.4 & -0.7 & -1.1 & -1.4 \\
\hline & \multirow[t]{2}{*}{ Moderate smoker } & Men & 1.9 & 2.4 & -0.4 & 0.5 & -2.3 \\
\hline & & Women & 1.9 & 1.1 & -1.1 & -0.8 & -3.0 \\
\hline & \multirow[t]{2}{*}{ Heavy smoker } & Men & 5.2 & 4.8 & 3.7 & -0.4 & -1.6 \\
\hline & & Women & 5.4 & 5.6 & 5.3 & 0.2 & -0.1 \\
\hline
\end{tabular}


heavy smokers could expect at least as many years with musculoskeletal diseases as never smokers, ex-, and moderate smokers (data not shown). Twenty year old men who will never begin to smoke, ex-smokers, moderate, and heavy smokers could expect 1.7 years, 3.5 years, 3.0 years, and 2.7 years encumbered with diseases of the respiratory system, respectively. The corresponding figures for 20 year old women were 2.0 years, 3.3 years, 3.0 years, and 5.2 years.

\section{SENSITIVITY ANALYSIS}

The results rely among other things on the relative risk estimates from DANCOS. To test how sensitive the results were to changes in relative risks, we estimated life tables and expected lifetime without longstanding illness using the upper limits of the $95 \%$ confidence intervals of the relative risk estimates, which were 1.3 for ex-smokers, 1.5 for moderate smokers, and 2.7 for heavy smokers. One result of this choice of relative risks was a less agreement between death rates aggregated over smoking category and the combined death rates of never smokers, ex-smokers, moderate smokers, and heavy smokers (that is, the right hand values of the equation $R=P_{-} R_{-}+P_{x} R$ $+\mathrm{P}_{+} \mathrm{R}_{+}+\mathrm{P}_{++} \mathrm{R}_{++}$, which was used to control the calculations, were generally too high, appendix 1). The life expectancy of 20 year old lifelong heavy smokers was reduced to 47.7 years for men and 51.9 years for women-that is, nine years lower than that of never smokers. The expected lifetime without longstanding illness was reduced by 0.7 years for male heavy smokers and 0.2 years for women, and the conclusions were not significantly affected by this change of relative risks.

Although individuals with poor health might be more likely not to participate in interview surveys about health, a difference in participation rates by smoking habit is implausible. Because the health of smokers is poorer than that of non-smokers, however, the differences in health expectancy might be slightly underestimated. Thus, if the proportion of persons suffering from longstanding illness were increased by $5 \%$, the difference in the expected lifetime without longstanding illness between 20 year old never smokers and lifelong heavy smokers would increase by 0.1 years.

\section{Discussion}

The main questions with regard to the validity of the results are whether:

- life tables for never smokers are reliable - that is, whether the estimate of smoking related mortality can be trusted;

- life tables for ex-smokers and smokers are reliable - that is, whether the DANCOS estimates of relative risks can be trusted;

- reports of smoking habits and self rated health and longstanding illness in the health interview surveys are reliable.

The first question addresses the validity of the method of Peto and colleagues ${ }^{4}$ for estimating smoking related mortality. The method was evaluated in two recent studies, both including mortality rates in Denmark, and the results were found to be reasonable. ${ }^{89}$ Thus, the numbers of smoking attributable deaths from lung cancer, chronic bronchitis, emphysema, ischemic heart disease, and stroke were estimated by the method of Peto and by the simulation model "Prevent", and close agreement between the two methods was found. ${ }^{8}$ The Prevent model $^{10}$ takes into account the development of smoking habits for a period of 20 years, whereas the Peto method does not require information about smoking, because the estimated synthetic smoking prevalence summarises the history of smoking in the population.

Two aspects must be considered in answering the second question: (1) the age and sex specific death rates in the various smoking categories must be consistent with the crude age and sex specific death rates-generally, we found the demand for consistency satisfactorily fulfilled; (2) when the relative risk estimates from DANCOS were replaced by the upper limits of the confidence intervals, as described in the section on sensitivity analysis, the gap between the life expectancy of never smokers and smokers was widened but did not change the conclusion as to differences in expected lifetime without longstanding illness between never smokers, ex-smokers, and smokers. Furthermore, the DANCOS estimates are fairly close to similar estimates from other studies including Danish data. ${ }^{11}$

Self reported data on smoking habits tend to result in an underestimate of smoking prevalence. ${ }^{12}$ This misclassification could lead to an underestimate of the difference in health expectancy between smoking categories. Another possible bias might be introduced by the non-response rate of $20 \%$ - for example, if the responders were healthier than the non-responders. The assumption that the prevalence of longstanding illness was in fact $5 \%$ higher did not alter the conclusion as to differences between smoking categories. The reliability of measures of self rated health has been investigated in several studies. Thus, the test-retest reliability of self rated health was found to be good or even better than that of more specific questions in two Swedish surveys. ${ }^{13}$ In a Danish study comprising three surveys it was concluded that self rated health is an independent concept. ${ }^{14}$ Moreover, a review of literature showed that self rated health is a powerful predictor of mortality and other health related end points. ${ }^{15}$ Thus, the answer to the third question is that the obvious weaknesses in health interview survey data will not invalidate the results.

The proportion of expected lifetime in self rated good health (table 1) or without longstanding illness (table 2) is shorter for women than for men. This is a general result and not specifically Danish. Differences between the sexes and between socioeconomic groups in health expectancy have been reported earlier. ${ }^{16}{ }^{17}$

We conclude that the estimates of health expectancy estimates are reliable and can withstand minor changes, reflecting the uncertainty 
of the parameters involved. The estimated difference is considered to be conservative because the aetiological fractions used to estimate smoking attributable mortality were adjusted downwards to ensure that the hazards of tobacco were not exaggerated, and because the possible bias introduced by the non-response rate of $20 \%$ in the health interview surveys tends to result in an underestimate of the differences in health expectancy.

In some studies on the effect of smoking on health, the influence of smoking on life expectancy was estimated, ${ }^{189}{ }^{18-24}$ and some studies focus on the economic consequences of smoking. ${ }^{23}{ }^{24}$ The results of these studies generally indicate that 6-9 life-years are lost because of smoking. Another key statistic is the mean years lost per death from smoking which was estimated at 13 years and 14 years for Danish men and women, respectively. ${ }^{1}$ The results from the various studies depend on the population (national or subpopulations, such as the British doctors) and the method of calculation-for example, whether ex-smokers are included in the group of non-smokers or whether smokers are divided into light, moderate, and heavy smokers. To our knowledge, only two studies of the extent of loss of life-years in good and in poor health have been published. A recent study on the relation between smoking, physical activity, and active life expectancy in a US population aged $\geqslant 65$ years showed that disability-free life expectancy was longest for never smokers who were physically active and shortest for inactive ever smokers. ${ }^{25}$ A Dutch study showed that abstention from smoking extends life and increases the length of time without disability. ${ }^{26}$

\section{CONCLUSION}

The life expectancy of a heavy smoker is a little more than seven years shorter than that of a never smoker. Smoking reduces the expected lifetime in self rated good health or without longstanding illness and increases the remaining life-years in poor health. Abstention from smoking thus compresses the duration of morbidity.

Appendix 1: construction of life tables for never smokers, ex-smokers, moderate smokers, and heavy smokers on the basis of the method of Peto and colleagues. ${ }^{4}$

Let L signify the sex and age specific Danish lung cancer death rate and $A$ and $C$ the lung cancer death rates among never smokers and smokers, respectively, according to the CPS-II. The "synthetic smoking prevalence" is then:

$$
\mathrm{P}=(\mathrm{L}-\mathrm{A}) /(\mathrm{C}-\mathrm{A})
$$

Let RR signify the CPS-II estimate of the relative risk for a smoking related disease other than lung cancer. Then, the aetiological fraction is:

$$
\frac{\mathrm{P}(\mathrm{RR}-1)}{1+\mathrm{P}(\mathrm{RR}-1)}
$$

In order to ensure that the hazards of tobacco are not exaggerated, the conservative estimate is used:

This method can be used to estimate sex and age specific mortality rates caused by smoking. Thus, sex and age specific death rates, $\mathrm{R}_{\text {- }}$, and a life table for never smokers can be estimated.
What is already known on this subject? Smoking increases the risk of various diseases and life expectancy is shorter for people who smoke than for people who do not smoke. A widespread opinion is that early death of smokers just spare them from poor health at the end of their lives. The question is whether, and if so, how much the expected lifetime in good health differs between never smokers and smokers.

\section{What this paper adds?}

Abstention from smoking not only extends life. It also compresses the duration of morbidity.

$$
\frac{\mathrm{P}(\mathrm{RR}-1)}{2+\mathrm{P}(\mathrm{RR}-1)}
$$

This life table for never smokers and estimates of relative risks for death can be used to calculate death rates for ex-smokers $\left(R_{x}\right)$, moderate smokers $\left(R_{+}\right)$, and heavy smokers $\left(R_{++}\right)$.

As a control for these calculations, the equation:

$$
\mathbf{R}=\mathbf{P}_{-} \mathbf{R}_{-}+\mathbf{P}_{\mathbf{x}} \mathbf{R}_{\mathbf{x}}+\mathbf{P}_{+} \mathbf{R}_{+}+\mathbf{P}_{++} \mathbf{R}_{++},
$$

where $\mathrm{R}$ is the death rate aggregated over smoking category, $\mathrm{P}_{-}$is the prevalence of never smokers, $\mathrm{P}_{\mathrm{x}}$ is that of ex-smokers, $\mathrm{P}_{+}$that of moderate smokers, and $\mathrm{P}_{+}$ that of heavy smokers, can be applied.

Life tables for ex-smokers, moderate smokers, and heavy smokers are constructed using the death rates $R_{\Varangle}$, $\mathrm{R}_{+}$, and $\mathrm{R}_{++}$.

\section{Appendix 2: calculation of health} expectancy by the method of Sullivan ${ }^{3}$

Let $1(x)$ and $e(x)$ signify the conventional life table figures of survivors and life expectancy at age $x$. If $\mathrm{p}(\mathrm{x}, \mathrm{x}+\mathrm{n})$ is the prevalence of good health at age $\mathrm{x}$ to $\mathrm{x}+\mathrm{n}$ among $\mathrm{N}(\mathrm{x}, \mathrm{x}+\mathrm{n})$ responders, then the expected years of life in good health among $1(\mathrm{x})$ survivors at age $\mathrm{x}$ to $\mathrm{x}+\mathrm{n}$ is:

$\mathrm{H}\left(\mathrm{x}_{1} \mathrm{x}+\mathrm{n}\right)=[\mathrm{l}(\mathrm{x}) \mathrm{e}(\mathrm{x})-\mathrm{l}(\mathrm{x}+\mathrm{n}) \mathrm{e}(\mathrm{x}+\mathrm{n})] \times \mathrm{p}\left(\mathrm{x}_{1} \mathrm{x}+\mathrm{n}\right)$

The health expectancy of $\mathrm{a}_{0}$ year old person is:

$$
\operatorname{HLE}\left(\mathrm{x}_{0}\right)=\frac{1}{1\left(\mathrm{x}_{0}\right)} \sum_{\mathrm{x}_{\mathrm{x}} \mathrm{x}_{0}, \mathrm{x}_{0}+\mathrm{n}, \ldots} \mathrm{H}(\mathrm{x}, \mathrm{x}+\mathrm{n})
$$

The variance of $\operatorname{HLE}\left(\mathrm{x}_{0}\right)$ is approximated by:

$$
\begin{aligned}
& \operatorname{Var}\left(\operatorname{HLE}\left(\mathrm{x}_{0}\right)\right)=\frac{1}{1^{2}\left(\mathrm{x}_{0}\right)} \\
& \sum_{\mathrm{x}=\mathrm{x}_{0}, \mathrm{x}_{0}+\mathrm{n}, \ldots}[1(\mathrm{x}) \mathrm{e}(\mathrm{x})-\mathrm{l}(\mathrm{x}+\mathrm{n}) \mathrm{e}(\mathrm{x}+\mathrm{n})]^{2} \times \\
& \frac{\mathrm{p}(\mathbf{x}, \mathbf{x}+\mathrm{n}) \times(1-\mathrm{p}(\mathrm{x}, \mathrm{x}+\mathrm{n}))}{\mathrm{N}(\mathrm{x}, \mathrm{x}+\mathrm{n})}
\end{aligned}
$$

1 Juel K. Hvorfor har danskerne problemer med middellevetiden? Rygningens betydning $i$ de seneste 50 år [Why is life expectancy a problem for the Danes? The influence of smoking over the last 50 years]. Ugeskr Lager 1998; 160:6800-5.

2 Fries JF. Ageing, natural death, and the compression of morbidity. N Engl f Med 1980;303:130-5.

3 Sullivan DF. A single index of mortality and morbidity. Health Services and Mental Health Administration (HSMHA) Health Reports 1971;86:347-54.

4 Peto R, Lopez AD, Boreham J, et al. Mortality from tobacco in developed countries: indirect estimation from national vital statistics. Lancet 1992;339:1268-78.

5 Kjøller M, Thomsen LK, Rasmussen NK. Befolkningens forebyggelse af Muskel- og skeletsygdom [Prevention of musculo-skeletal disease in the population]. Copenhagen: DICE, 1993 (in Danish) 
6 Kjøller M, Rasmussen NK, Keiding L, et al. Sundhed og sygelighed i Danmark 1994 - og udviklingen siden 1987. [Danish Health and Morbidity Survey 1994]. Copenhagen: DICE, 1995 (in Danish)

7 Health expectancy calculation by the Sullivan method: a practical guide. European concerted action on harmonization of health expectancy calculations in Europe (EURO-

8 Brønnum-Hansen H, Juel K. Estimating mortality due to cigarette smoking. Two methods, same result. Epidemiology 2000;11:422-6.

9 Valkonen T, van Poppel F. The contribution of smoking to sex differences in life expectancy. Four Nordic countries and the Netherlands 1970-1989. Eur 7 Public Health 1997;7:302-10.

10 Gunning-Schepers LJ. The health benefits of prevention: a simulation approach. Health Policy 1989;12:1-256.

11 Prescott E, Osler M, Andersen PK, et al. Mortality in women and men in relation to smoking. Int $\mathcal{F}$ Epidemiol women and men

12 Patrick DL, Cheadle A, Thompson DC, et al. The validity of self-reported smoking: a review and meta-analysis. $A m \mathcal{F}$ Public Health 1994:84:1086-93.

13 Lundberg O, Manderbacka K. Assessing reliability of a measure of self-rated health. Scand f Soc Med 1996; 24:218-24

14 Kristensen TS, Bjørner J, Smith-Hansen L, et al. Selvvurderet helbred og arbejdsmiliø-Er selvvurderet helbred et frugtbart og nyttigt begreb $i$ arbejdsmiljøforskning og forebyggelse? [Self-rated health and work environment-Is self-rated health a productive and useful concept in work environmental research and prevention?]. Copenhagen, Working Environment Foundation, 1998 (in Danish).

15 Idler EL, Benyamini Y. Self-rated health and mortality: A review of twenty-seven community studies. F Health Soc Behav 1997;38:21-37.
16 Brønnum-Hansen $H$. Trends in health expectancy in Denmark, 1987-1994. Dan Med Bull 1998;45:217-21.

17 Brønnum-Hansen H. Socioeconomic differences in health expectancy in Denmark. Scand f Public Health 2000; 28:194-9.

18 Prescott E, Osler M, Hein HO, et al. Life expectancy in Danish women and men related to smoking habits: smoking may affect women more. $\mathcal{F}$ Epidemiol Community Health 1998;52:131-2.

19 Phillips AN, Wannamethee SG, Walker M, et al. Life expectancy in men who have never smoked and those who have smoked continuously: 15 year follow up of large cohort of middle aged British men. BMF 1996;313:907-8.

20 Doll R, Peto R, Wheatley $\mathrm{K}$, et al. Mortality in relation to smoking: 40 years' observations on male British doctors. BMF 1994;309:901-11.

21 Basavaraj S. Smoking and loss of longevity in Canada. Can 7 Public Health 1993;84:341-5.

22 Rogers RG, Powell-Griner E. Life expectancies of cigarette smokers and nonsmokers in the United States. Soc Sci Med 1991;32:1151-9.

23 Barendregt JJ, Bonneux L, van der Maas PJ. The health care costs of smoking. N Engl f Med 1997;337:1052-7.

24 Welte R, König HH, Leidl R. The costs of health damage and productivity losses attributable to cigarette smoking in Germany. Eur f Public Health 2000;10:31-8.

25 Ferrucci L, Izmirlian G, Leveille S, et al. Smoking, physical activity, and active life expectancy. $A m$ f Epidemiol 1999;149:645-53.

26 Nusselder WJ, Looman CWN, Marang-van de Mheen PJ, et al. Smoking and the compression of morbidity. $f$ Epidemiol Community Health 2000;54:566-74.

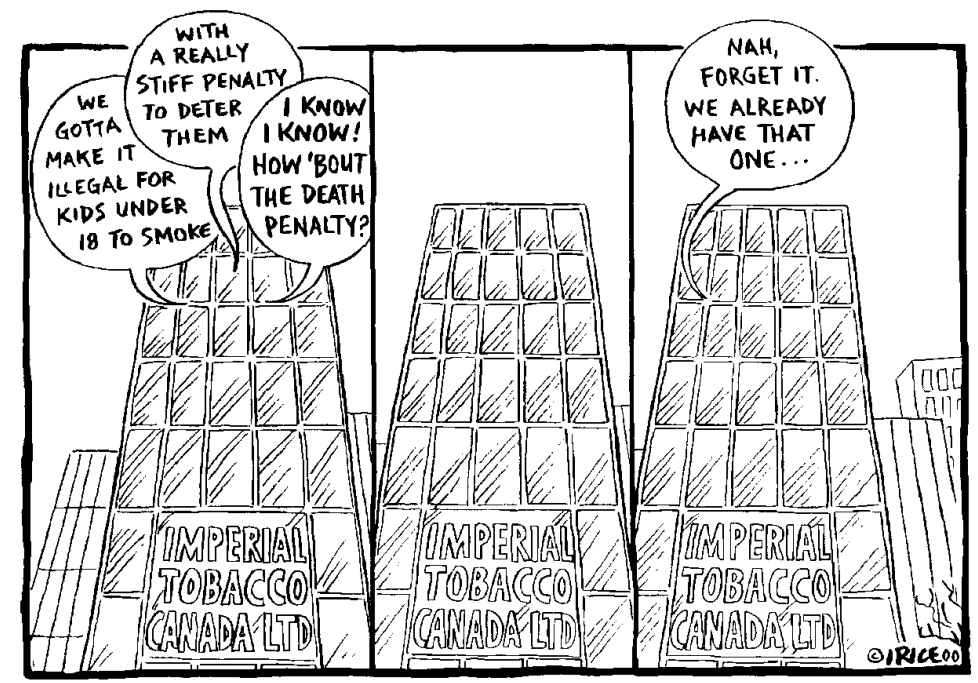

(c) Ingrid Rice. 